\title{
Localized Adrenal Gland Pheochromocytoma
}

National Cancer Institute

\section{Source}

National Cancer Institute. Localized Adrenal Gland Pheochromocytoma. NCI Thesaurus.

Code C27279.

A pheochromocytoma that does not invade surrounding tissues and is confined to the adrenal glands. 